\title{
The Technical Design Concept of Hi-Tech Cook Stove for Urban Communities using Non-Wood Agricultural Waste as Fuel Sources
}

\author{
Erkata Yandri $^{1,2, *}$, Bangun Novianto ${ }^{1}$, Fridolini Fridolini ${ }^{3}$, Roy Hendroko Setyabudi ${ }^{1,4}$, \\ Haryo Wibowo ${ }^{5}$, Satriyo Krido Wahono ${ }^{6}$, Kamaruddin Abdullah ${ }^{1,2}$, Washington Purba ${ }^{1}$, \\ and Yogo Adhi Nugroho ${ }^{7,8}$
}

\begin{abstract}
${ }^{1}$ Graduate School of Renewable Energy, Darma Persada University, J1. Radin Inten 2, Pondok
Kelapa, East Jakarta 13450, Indonesia

${ }^{2}$ Center of Renewable Energy Studies, Darma Persada University, Jl. Radin Inten 2, Pondok Kelapa, East Jakarta 13450

${ }^{3}$ English Language Study Program of Vocational, Faculty of Language and Culture, Darma Persada University, Jl. Radin Inten 2, Pondok Kelapa, East Jakarta 13450, Indonesia

${ }^{4}$ Department of Agriculture Science, Postgraduate Program, University of Muhammadiyah Malang, J1. Raya Tlogomas No. 246, Malang, 65145, Indonesia

${ }^{5}$ Institute of Energy and Power Engineering, Zhejiang University of Technology, No. 38 Zheda Road Hangzhou 310027, P.R. China.

${ }^{6}$ Research Division for Natural Product Technology - Indonesian Institute of Sciences,

Jl. Jogja - Wonosari, km 31.5, Gunung Kidul, Special Region Yogyakarta 55861, Indonesia

${ }^{7}$ Individual Researcher, Alumni Graduate School of IPB University, Bogor, Indonesia

${ }^{8}$ Data Processing, Rumah Paper - Editage Services, J1. Tokala No.1, Malang 65146,

East Java, Indonesia
\end{abstract}

\begin{abstract}
The purpose of this study is to conceptualize an urban Hi-Tech CookStove (HTCS) design using agricultural waste. Several steps need to be carried out. First, determine the cooking activities depend on the family size and food categories. Second, calculate the energy required for cooking. Third, determine the mass of biomass fuel required. Fourth, calculate the fuel consumption rate. Fifth, design the dimensions of the stove by considering the ergonomics, easy in manufacturing, installation, etc. Sixth, estimate the volume of each component. The result shows that the fuel supply must adjust the flow rate of fuel, air to fuel ratio controlled by a simple mechanical-electric compressor, monitor the combustion chamber visually/automatically, and the dust must be collected/disposed of automatically/ mechanically. HTCS must consider the pellets from the higher heating value and faster of biomass with a certain composition of chopped and fibre, also the safety and comfort, such as overheating control, air exhaust control, combustion control, cooling control. For the future, the HTCS technical design concept must be integrated with the electricity and hot water from solar energy by using a hybrid photovoltaic-thermal (PVT) collector and urban biogas digester in the development of smart grids and smart cities.
\end{abstract}

Keywords: Renewable energy integration, energy efficient building, briquette, pellet, rural development

\footnotetext{
*Corresponding author: erkata@gmail.com; erkata@pasca.unsada.ac.id
} 


\section{Introduction}

As a tropical and agrarian country, Indonesia has a large potential of biomass from solid agriculture waste from palm oil, coconut, rubber, sugar, rice, and corn, which can be converted to solid, liquid, and gas energy [1]. Unfortunately, the utilization of biomass as energy has not been maximized yet. Technically, the yearly potential of agricultural waste in Indonesia is approximately 614.6 PJ [2]. The solid agricultural waste [3, 4], can be processed into pellets or briquettes, with uniform energy content, easily stored and transported. One of the uses of biomass solid waste is for cooking, using biomass stoves. Solid biomass gives a unique aroma and taste sensation to food, although the smoke factor must still be a serious concern. The problem is, the image of biomass stoves, especially in Indonesia, is identical to the modest tech stoves for people in low-income rural areas. Generally, rural improved cook stove programs are promoted by donors to empower women in reducing poverty [5]. Meanwhile, people in urban areas are comfortable with the ease of clean gas stoves. If there were biomass stoves made with high technology for certain urban communities, with biomass fuel from agricultural waste from pellets made by rural people, this would have significant energy, environmental and economic impact for the country, leading to national energy security [6].

The design of biomass stoves has attracted many researchers and non-government organizations around the world. There have been many efforts that have been done by various parties, both government and non-government organizations (NGOs), such as designing and promoting biomass stoves, to utilize cheap energy from agricultural waste, increase fuel efficiency, and at the same time empower the rural economy [7]. Last et al. [8] disseminated the improved traditional Haitian stove as an efficient energy stove. Raman et al. [9] evaluated the fuel flexibility, efficiency, and user acceptance with the boiling test to the three types of forced draft cookstove with wood and coconut shell fuels. Yulianto et al. [10] designed and tested a Stove for Combine Heat Power biomass using coconut shell by controlling some parameter, resulting in the flue gas and combustion chamber temperature can reach $520{ }^{\circ} \mathrm{C}$ and $840{ }^{\circ} \mathrm{C}$, respectively. Agustina and Hafidaturrohmah [11] designed a biomass stove using corncob, coconut shell, and wood chips as biomass fuel and evaluated some parameters related to the thermal efficiency, combustion efficiency, specific fuel consumption, emission of $\mathrm{CO}$ and particulate emissions were evaluated. Nurhuda [12] created a biomass semi gasification stove with a pre-heating system using chopped wood, oil palm shells, hazelnut, corn cobs or pellets or briquettes from agricultural/plantation waste, thus saving $60 \%$ to $80 \%$ fuel compared to traditional biomass stoves.

Based on the above review, many biomass stoves have been developed for rural communities with various technical parameters to make them healthier and more efficient. However, not many biomass stoves are designed according to the needs of urban communities, especially for the upper-middle level. The challenge is how to design stoves with smaller-mass components that also have acceptable durability, affordable cost, the decisive socio-cultural, increasing the life of a cook-stove through a better choice of materials, ease of operation and maintenance, and meet user needs with economics and modern technology [13-15], by utilizing agricultural waste as fuel [12]. Based on these considerations, the purpose of this study is to conceptualize a Hi-Tech cook-stove design using pellets and briquettes as fuel from solid biomass agricultural waste non-wood produced by rural people for certain urban communities. The design of HTC supports the general concept of future household clean energy models [4] and empowering the rural economy by treating agricultural waste [12]. 


\section{The design of hi-tech cook stove (HTCS)}

Figure 1 shows the combustion chamber concept design of Hi-Tech Cook Stove (HTCS). The reason to choose the combustion chamber type stove because it seems to burn wood more effectively at varying moisture content, compared to the open fire or rocket type stoves [16]. The design consists of several main components, such as; fuel supply system (FSS) as a biomass fuel feeder, pressured air system (PAS) as an oxygen supplier during combustion, combustion chamber system (CCS) as a place for combustion, bottom ashtray system (BAS) as a bottom ash collector for combustion results, and is equipped with a combustion regulator system (CRS) button to adjust the Low-Mid-High calibrated with FSS and PAS.

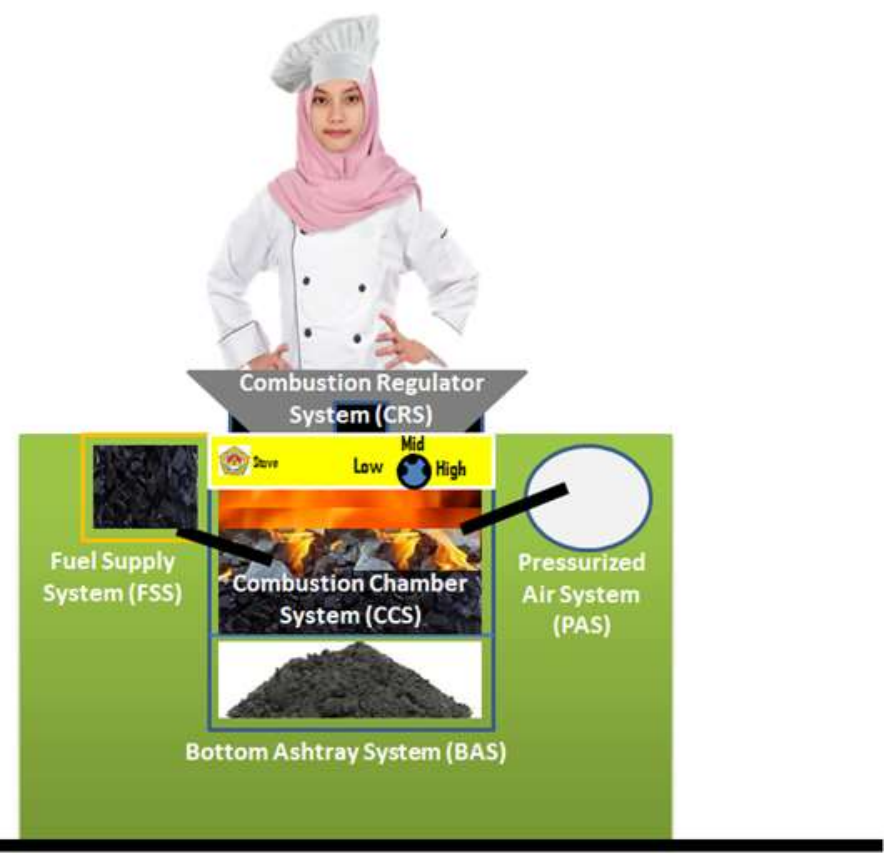

Fig. 1. Concept design of Hi-Tech Cook Stove (HTCS)

\section{Method}

To determine the dimensions and operational parameters of each HTCS component, several steps need to be carried out as follows:

First, determine the cooking activities depend on the family size and food categories. These factors affect the energy required and times for cooking. The family size is divided into three, such as small family (three members: father, mother, and a child), middle family (five members: father, mother and three children), large family (more than six members: father, mother, and more than three children). The cooking category is divided into fast cooking (5 $\mathrm{min}$ to $10 \mathrm{~min}$ ), medium cooking (10 $\mathrm{min}$ to $20 \mathrm{~min}$ ) heavy cooking (more than $20 \mathrm{~min})$.

Second, calculate the energy required for cooking $Q_{c}[\mathrm{~J}]$

$$
Q_{c}=\dot{m}_{c} c_{p, c} \Delta T_{c}
$$


where, $\dot{m}_{c}$ is the mass of cooked food $[\mathrm{kg}], c_{p, c}$ is a specific heat from cooking ingredients $\left[\mathrm{kJ} \mathrm{kg}^{-1}{ }^{\circ} \mathrm{C}^{-1}\right]$ of selected foods [17-19], $\Delta T_{c}$ is the different temperature of cooking after and before $\left[{ }^{\circ} \mathrm{C}\right]$.

Third, determine the mass of biomass fuel required $m_{b b}$;

$$
m_{b b}=\frac{Q_{c}}{C_{v} \times E f f}
$$

Where $C_{v}$ is the heating value of biomass fuel $\left[\mathrm{J} \mathrm{kg}^{-1}\right]$, and Eff is the standard combustion efficiency of biomass to heat energy [\%].

Fourth, calculate the fuel consumption rate $\left[\mathrm{g} \mathrm{min}^{-1}\right]$ with:

$$
F C R=\frac{m_{b b}}{t}
$$

Where, $t$ is the total times require for cooking [min]. It refers to the amount of energy supplied by the fuel into the combustion chamber.

Fifth, design the dimensions of the stove by considering several factors, such as ergonomics for the user during cooking, easy in manufacturing, easy installation, easy to use, easy to move, easy to maintain, etc. Based on these items, the dimensions of the stove are designed $1.6 \mathrm{~m} \times 0.8 \mathrm{~m} \times 0.8 \mathrm{~m}$ for length, height and width, respectively. The volume of the stove must adjust the dimensions and position of the main stove components.

Sixth, estimating the volume of each component:

(i) FSS: calculated from Equation (2) and fuel density $\bar{V}_{b b}\left[\mathrm{~kg} \mathrm{~m}^{-3}\right]$ with assumption variables $n$ as the frequency of refuelling in a day, Then $V_{f s s}\left[\mathrm{~m}^{3}\right]$ is as follows;

$$
V_{f s s}=n\left(\frac{m_{b b}}{\bar{V}_{b b}}\right)
$$

(ii) PAS: calculated from Equation (1) with $\mathrm{O}_{2}$ required during hourly cooking, then $V_{p a s}$ $\left[\mathrm{m}^{3}\right]$ is as follows [20]: when $\varepsilon=0.3$, stoichiometric air $(S A)$ is $4.5 \mathrm{~kg}_{\text {air }} \mathrm{kg}_{\text {fuel }}{ }^{-1}$ and air density $\rho_{a}=1.29 \mathrm{~kg} \mathrm{~m}^{-3}$ and air compression factor $f_{c}=0.5$.

$$
V_{\text {pas }}=\frac{\varepsilon \times F C R \times 60 \times S A}{\rho_{a}} f_{c}
$$

(iii)CCS: calculated from Equation (2) with consideration of volume tolerance for optimal combustion, then $V_{c c s}$ is as follows: Diameter of CCS: assuming the combustion rate (SBR) specification is $40 \mathrm{~kg} \mathrm{~m}^{-2} \mathrm{~h}^{-1}$. Then $\mathrm{D}[\mathrm{m}$ ] is as follows:

$$
D=\left(\frac{1.27 \times F C R}{S B R}\right)^{0.5}
$$

Height of CCS: if it is assumed that the use of stove without refuelling can work for $6 \mathrm{~h}(\mathrm{~T})$ and fuel density $\bar{V}_{b b}\left[\mathrm{~kg} \mathrm{~m}^{-3}\right]$. Then the CCS height $\mathrm{H}[\mathrm{m}]$ is:

$$
H=\frac{S B R \times T}{\bar{V}_{b b}}
$$

The volume of CCS;

$$
V_{c c s}=\pi \times r^{2} \times h
$$


where, $r$ is the radius of the stove [m] and $h$ is the distance between the stove and the cauldron assumed to be $3 \mathrm{~cm}$. The dimension of CCS should be designed properly to prevent excess fuel loading for decreasing fuel consumption while cooking [21].

(iv) BAS: calculated from the combustion residue ash from Equation (2) with estimated residual $(\delta) 5 \%$ and the maximum accumulation of cooking frequency, then $V_{b a t}$ is as follows:

$$
V_{b a s}=n\left(\frac{\delta \times m_{b b}}{\bar{V}_{b b}}\right) 10^{6}
$$

All aspects of the technical design must refer to internationally accepted standards and protocols, which must be considered during the development process by identifying, avoiding and overcoming errors in the design or system concept [22].

\section{Result and discussion}

Figure 2 illustrates the relationship between biomass needed and family size. Figure 2(a) shows the energy required for cooking in a day is proportional to the family size and cooking frequency. The energy required will also increase with increasing cooking time. Figure 2(b) shows the amount of energy required $(\mathrm{kg})$ for cooking in a day with different types of biomass in pellets and briquettes. The amount of energy (in $\mathrm{kg}$ ) depends on the caloric value (in $\mathrm{J} \mathrm{kg}^{-1}$ ) of the type of biomass, the higher the caloric value, the lower the biomass consumed (in $\mathrm{kg}$ ).

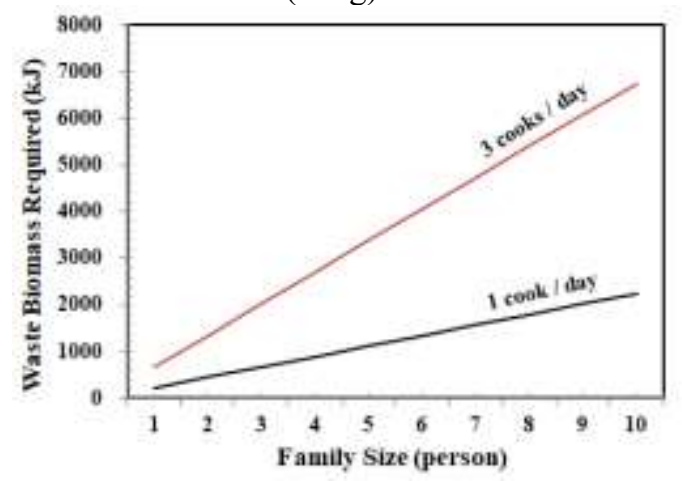

(a)

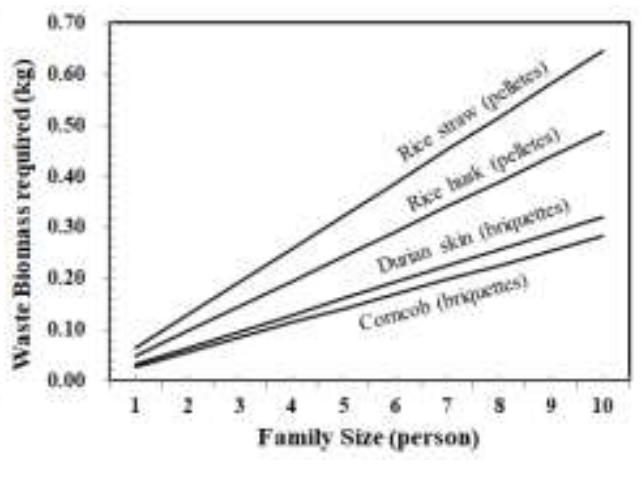

(b)

Fig. 2. Waste biomass required, a). One cook d $\mathrm{d}^{-1}$ vs. three cooks d $\left.\mathrm{d}^{-1}, \mathrm{~b}\right)$. Different biomass and types

Table 1 is the dimensions of CCS based on the high heating value,, the briquettes of corncob, and the pellets of palm oil trees, as the reference in design calculations. With higher fuel density, palm oil tree pellets provide shorter CCS heights compared to corncob briquettes. 
Table 1. Specification design for CCS using briquettes and pellets

\begin{tabular}{ccccc}
\hline \multirow{2}{*}{ Type } & \multirow{2}{*}{ Biomass Waste } & Fuel Density & \multicolumn{2}{c}{ CCS } \\
& & & D (m) & H (m) \\
\hline Briquettes & Corncob & 857 & 0.14 & 0.28 \\
Pellets & Palm oil tree & 1200 & 0.15 & 0.20 \\
\hline
\end{tabular}

The volume and consideration for system components of HTCS are summarized in Table 2. The volume of system components is highly dependent on pellets or briquettes biomass. For ease of use, biomass pellets are considered in the HTCS technical design concept. Biomass stoves available today still cannot replace LPG stoves. This is the challenge that HTCS has to answer, how users still feel as comfortable as using an ordinary gas stove.

Table 2. Summary volume and consideration for system components

\begin{tabular}{llll}
\hline \multirow{2}{*}{ System Components } & \multicolumn{2}{c}{ Volume $\left(\mathbf{c m}^{3}\right)$} & \multicolumn{1}{c}{ Design Consideration } \\
& Briquettes & Pellets & \multicolumn{1}{c}{} \\
\hline FSS & 375 & 283 & The fuel supply adjusts the flow rate \\
PAS & 4935 & 5917 & $\begin{array}{l}\text { Simple mechanical-electric compressor application } \\
\text { CCS }\end{array}$ \\
462 & 530 & $\begin{array}{l}\text { Combustion chamber is monitored } \\
\text { visually/automatically }\end{array}$ \\
BAS & 48 & 42 & $\begin{array}{l}\text { Dust is collected/disposed of } \\
\text { automatically/mechanically }\end{array}$ \\
\hline
\end{tabular}

Based on what has been explained before, then three things need to be discussed further. First, related to the type and composition of pellets to be used as fuel. Following HTCS specifications for immediate cooking, it is necessary to consider the type and composition of biomass for pellets [10-12]. For this reason, pellets must be produced from high heating value biomass, with a certain composition of chopped and fibre. Second, related to safety and comfort. Both of these must be an integral part of the design, prototyping and testing of HTCS. There are several important systems to be studied in more detail, such as overheating control, air exhaust control, combustion control, cooling control, etc [13-15]. To ensure the availability of fuel supply during cooking, it is necessary to design fuel supply from other sources, for example, biogas from kitchen waste digester or septic tank digester. Thus, CCS design must also be adjusted for biogas. Third, related to the standard test. HTCS must pass the following test items, such as; boiling test, time for initial start-up test, rise test, air to fuel ratio test, firing test (Low, Mid, High), etc.

In practice, HTCS must be directly applied to cook all types of cuisine, as well as the application of modern gas and electric stoves [14]. For the initial stage, HTCS was promoted for the urban middle-upper class community, which is considered easy to educate financially and operationally on this high-tech stove. In addition to contributing to utilizing non-woody biomass waste and reducing fossil energy dependency, HTCS also has an economic impact by empowering rural communities as producers of pellets and briquettes as biomass fuels [23, 24]. For future research directions, the HTCS technical design concept must be realized and tested with the special functions of the main components. In addition, with the development of smart grids, smart cities and energy efficiency in urban areas [25-27], it is also important to consider the integration of electricity and hot water from solar energy by using a hybrid photovoltaic-thermal (PVT) collector [28, 29] and future development of urban biogas digester. 
The application of biogas is feasible to manage kitchen waste and excreta disposal from septic tanks in urban areas for environment friendly [30-33]. The two-stage digester system is recommended because kitchen waste tends to be acidic and float [34, 35]. Waste management is essential because it harms human health [36, 37].

\section{Conclusion}

A Hi-Tech Cook Stove (HTCS) concept has been designed for urban communities by utilizing non-wood agricultural waste into pellets as fuel. With dimensions of length = $1.6 \mathrm{~m}$, width $=0.8 \mathrm{~m}$, and height $=0.8 \mathrm{~m}$, all important components of HTCS, such as CCS (combustion chamber system), FSS (fuel supply system), PAS (pressurized air system), and BAS (bottom ashtray system) are designed inside the stove. To meet operational standards, the HTCS must refer to; high heating value pellet, high levels of safety and comfort and pass certain standard tests. Further development integrates HTCS with other renewable energy sources such as electricity and heat from the PVT collector and biogas from the urban biogas digester in the development of smart grids and smart cities.

\section{References}

1. N.L. Panwar, R. Kothari, V.V. Tyagi, Renew. Sustain. Energy Rev., 16,4:18011816(2012). https://www.sciencedirect.com/science/article/pii/S1364032112000251

2. IRENA, Renewable Energy Prospects in Indonesia, Abu Dhabi: IRENA(2017). https://www.irena.org//media/Files/IRENA/Agency/Publication/2017/Mar/IRENA_REmap_Indonesia_repor t_2017.pdf

3. S.S. Harsono, B. Prayogo, M. Mel, F. Ridha, Journal of Advanced Research in Fluid Mechanics and Thermal Sciences, 2,2:215-226(2018). http://www.akademiabaru.com/doc/ARFMTSV51_N2_P215_226.pdf

4. A.K. Quinn, N. Bruce, E. Puzzolo, K. Dickinson, R. Sturke, D.W. Jack, et al., Energy Sustain. Dev., 46:1-10(2018). https://www.sciencedirect.com/science/article/pii/S0973082618302679

5. M. Kees, L. Feldmann, Energy Policy, 39,12:7595-7599(2011). https://www.sciencedirect.com/science/article/pii/S0301421511002102

6. E. Yandri, R. Ariati, R.F. Ibrahim, J. Ketahanan Nas., 24,2:239-260(2018). [in Bahasa Indonesia]. https://dev.jurnal.ugm.ac.id/jkn/article/view/30999

7. S.A. Mehetre, N.L. Panwar, D. Sharma, H. Kumar, Renew. Sustain. Energy Rev., 73:672-687(2017). https://www.sciencedirect.com/science/article/pii/S1364032117301648

8. K. Lask, K. Booker, T. Han, J. Granderson, N. Yang, C. Ceballos, et al., Energy Sustain. Dev., 26:79-86(2015). https://www.sciencedirect.com/science/article/pii/S0973082615000101

9. P. Raman, J. Murali, D. Sakthivadivel, V.S. Vigneswaran, Biomass and Bioenergy, 49:333-340(2013). https://www.sciencedirect.com/science/article/pii/S0961953412005260

10. M. Yulianto, S.E. Agustina, E. Hartulistiyoso, L. Oscar, AIP Conference Proceedings, 1826:020031(2017); https://doi.org/10.1063/1.4979247

11. N. Agustina, H. Hafidaturrohmah, E3S Web Conf., 67,02034:1-8.(2018). https://www.e3s-conferences.org/articles/e3sconf/abs/2018/42/e3sconf_itrec2018_02034/e3sconf_i-trec2018_02034.html

12. M. Nurhuda, Majalah Energi dan Mineral, 9,4:4-10(2011). [in Bahasa Indonesia]. https://litbang.esdm.go.id/publikasi/5908-majalah-energi-dan-mineral/8965-majalah- 
mineral-dan-energi-desember-2011

13. J.K. Jetter, P. Kariher, Biomass and Bioenergy, 33,2:294-305(2009).

https://www.sciencedirect.com/science/article/pii/S0961953408001505

14. M.P. Kshirsagar, V.R. Kalamkar, Renew. Sustain. Energy Rev., 30:580-603(2014). https://www.sciencedirect.com/science/article/pii/S136403211300748X

15. K.B. Sutar, S. Kohli, M.R. Ravi, A. Ray, Renew. Sustain. Energy Rev., 41:11281166(2015). https://www.sciencedirect.com/science/article/pii/S136403211400776X

16. E.A.T. Yuntenwi, N. MacCarty, D. Still, J. Ertel, Energy Sustain. Dev., 12,2:6677(2008). https://www.sciencedirect.com/science/article/pii/S0973082608604305

17. E. Contreras-Gallegos, F.A. Domínguez-Pacheco, C. Hernández-Aguilar, J.A. Salazar-Montoya, E.G. Ramos-Ramírez, A. Cruz-Orea, J. Therm. Anal. Calorim., 128,1:523-531(2017). https://link.springer.com/content/pdf/10.1007/s10973-0165864-1.pdf

18. F.S. Carrillo, L. Saucier, C. Ratti, Int. J. Food Prop., 20,3:573-584(2017). https://www.tandfonline.com/doi/abs/10.1080/10942912.2016.1171776

19. K.D. Barine, N. Victor, Journal of Food Technology Research, 3,1:23-272016). http://www.conscientiabeam.com/pdf-files/agr/58/JFTR-2016-3(1)-23-27.pdf

20. A.T. Belonio, Rice husk gas stove handbook. Philippines: Central Philippine University, (2005). http://bioenergylists.org/stovesdoc/Belonio/Belonio gasifier.pdf

21. S. Bentson, D. Still, R. Thompson, K. Grabow, Energy Sustain. Dev., 17,2:153157(2013). https://www.sciencedirect.com/science/article/pii/S0973082612000804

22. Z. Zhang, Y. Zhang, Y. Zhou, R. Ahmad, C. Pemberton-Pigottc, H. Annegarn, et al., Renew. Sustain. Energy Rev., 72:1343-1354(2016). https://www.sciencedirect.com/science/article/pii/S136403211630692X

23. E. García-Frapolli, A. Schilmann, V.M. Berrueta, H. Riojas-Rodríguez, R.D. Edwards, M. Johnson, et al., Ecol. Econ., 69,12:2598-2605(2010). https://www.sciencedirect.com/science/article/pii/S0921800910003289

24. B. Novianto, K. Abdullah, A.S. Uyun, E. Yandri, S.M. Nur, H. Susanto, et al., E3S Web of Conferences 188:00005(2020) https://doi.org/10.1051/e3sconf/202018800005

25. E. Yandri, R.H. Setyobudi, H. Susanto, K. Abdullah, Y.A. Nugroho, S.K. Wahono, et al., E3S Web of Conferences 188:00007(2020).

https://doi.org/10.1051/e3sconf/202018800007

26. E. Yandri, R. Ariati, A.S. Uyun, R.H. Setyobudi, H. Susanto, K. Abdullah, et al., E3S Web of Conferences 190:0008(2020) https://doi.org/10.1051/e3sconf/202019000008

27. E. Yandri, Renew. Energy, 111:344-352(2017). https://www.sciencedirect.com/science/article/pii/S0960148117302860

28. S.S. Harsono, R. Dila, M. Mel, J. Environ. Sci. Curr. Res. 2:004(2019). http://www.heraldopenaccess.us/openaccess/coffee-husk-biopellet-characteristics-assolid-fuel-for-combustion-stove

29. E. Yandri, Sol. Energy Mater. Sol. Cells, 201:10066(2019). https://www.sciencedirect.com/science/article/pii/S0927024819303952

30. R. Hendroko, T. Liwang, Salafudin, L.O. Nelwan, G.A. Praptiningsih, S.K. Wahono, Biorefinery skala rumah tangga: integrasi energi terbarukan - biogas dan pangan [Household scale biorefinery: integration of renewable energy - biogas and food]. Seminar Hasil Penelitian Semester Ganjil 2011/2012, Lembaga Penelitian, Pemberdayaan Masyarakat dan Kemitraan Universitas Darma Persada, (Jakarta, Indonesia, 2012), pp. 1-13. [in Bahasa Indonesia] http://lp2mk.unsada.ac.id/wpcontent/uploads/2016/04/PROSIDING-GJL-11-12.pdf

31. R. Hendroko, T. Liwang, Salafudin, G.A. Praptiningsih, L.O. Nelwan, Y. Sakri, et al., Sinergi bio-metana berbahan baku limbah Jatropha curcas $L$., dan pangan dalam penerapan program kawasan rumah pangan lestari [Synergy of bio-methane made 
from Jatropha curcas L. waste, and food in the implementation of sustainable food home area program]. Prosiding Simposium dan Seminar Bersama PERAGIPERHORTI-PERIPI-HIGI, (Bogor, Indonesia, 2012), pp. 437-443. [in Bahasa Indonesia] http://lipi.go.id/publikasi/sinergi-bio-metana-berbahan-baku-limbahjatropha-curcas-1-dan-pangan-dalam-penerapan-program-kawasan-rumah-pangan$\underline{\text { lestari/20594 }}$

32. K. Abdullah, A.S. Uyun, R. Soegeng, E. Suherman, H. Susanto, R.H. Setyobudi, et al., E3S Web of Conferences 188:00016(2020). https://doi.org/10.1051/e3sconf/202018800016

33. H. Susanto, R.H. Setyobudi, D. Sugiyanto, S.M. Nur, E. Yandri, H. Herianto, et al., E3S Web of Conferences 188:00010(2020). https://doi.org/10.1051/e3sconf/202018800010

34. P.G. Adinurani, T. Liwang, Salafudin, L.O. Nelwan, Y. Sakri, S.K. Wahono, et al., Energy Procedia, 32:84-89(2013).

https://www.sciencedirect.com/science/article/pii/S1876610213000131

35. P.G. Adinurani, R.H. Setyobudi, S.K. Wahono, A. Sasmitod, L.O. Nelwan,

A. Nindita, et al., International Journal of Renewable Energy Development, 3,1:7378(2014). https://doi.org/10.14710/ijred.3.1.73-78.

36. K. Khoiron, A.N. Probandari, W. Setyaningsih, H.S. Kasjono, R.H. Setyobudi, O. Anne, Ann Trop \& Public Health S463, 23,3(A):60-67(2020). http://doi.org/10.36295/ASRO.2020.23316

37. M. Soleh, H. Hadiyanto, J. Windarta, O. Anne, R.H. Setyobudi, M. Mel . E3S Web of Conferences 190:00027(2020). https://doi.org/10.1051/e3sconf/202019000027 